\title{
Use of Cement Stabilized Rammed Earth for Load Bearing Wall with Appropriate Finishes-Case Study
}

\author{
G.W.T.C. Kandamby \\ Division of Civil Engineering Technology, Institute of Technology, University of Moratuwa, Sri Lanka \\ Received 01 Feb 2018, Accepted 01 April 2018, Available online 02 April 2018, Vol.8, No.2 (March/April 2018)
}

\begin{abstract}
Rammed earth is one of the traditional technology used for putting up houses in most parts of the world and it is being now rapidly developed through researches due to its valuable qualities especially strength, durability, environmental friendly and affordability. As a result, cement has been introduced as a stabilizer to gain high strength and durability. Local building codes and guidelines have been established to design and construct rammed earth walls successfully in buildings. Aim of this paper is to demonstrate the application of cement stabilized rammed earth for making load bearing walls of two storey house combining with reinforced cement concrete beams, lintels, slab and stairway. These walls have been structurally designed by following the code of engineering design of earth buildings NZS 4297:1998 published by New Zealand and applying strength parameters derived for local soils. House construction was totally completed in 2015 with smooth and rough wall finishes for internal and external surfaces of walls to get the good appearance to the house.
\end{abstract}

Keywords: Rammed earth, Cement stabilizer, Two storey house, Load bearing walls, Engineering design, Wall finishes.

\section{Introduction}

Construction of houses in cities and suburbs of Sri Lanka is being rapidly increased by focusing on putting up two storey houses due to high price and the scarcity of lands. Housing sector has an impact on the environment in land use for housing, use of natural resources for construction and energy consumption. Earth is a natural material which requires no energy to produce and give natural comfort and humidity. Unbaked earth has been used for buildings since ancient times, as shown by the thousands of buildings disseminated throughout the world (Delgado \& Guerrero, 2005). The utilization of earth in housing construction is one of the oldest and most common methods used by a larger percentage of the developing countries' population (Arumala \& Gondal, 2007). It has been widely used for thousands of years and still today. It is an effective and an economic form for housing construction and according to the United Nations, about a third of the world's population live in earthen structures today (Arumala \& Gondal, 2007). Sri Lanka has also used earth for building shelters during colonial period and thereafter mainly used kabook which has been taken as a rectangular shape of pieces

*Corresponding author's ORCID ID: 0000-0003-3934-4022 DOI: https://doi.org/10.14741/ijcet/v.8.2.18 from very hard and strong gravel encountered in underground areas (Bogahawatte, 1993). Locally available earthen material used in buildings contributes to the maintenance of a balanced ecology, because earthen material has low embodied energy when compared with other building materials (Isik \& Tulbentci, 2008). Nowadays, earth is a typical building material, but has a number of qualities that make it stand out from other materials by balancing air humidity, acting as high thermal mass and is available almost anywhere in the world; it is highly fire resistant (Ciurileanu \& Horvath, 2012).

Two storey house was constructed in 2014 using CSRE load bearing walls in ground floor area combining reinforced cement concrete (R.C.C) beams and continuous lintels where necessary by performing structural design as per New Zealand code of practice for engineering design of earth building (NZS 4297: 1998). Total construction of this house was completed in 2015 and the house was occupied in 2015. Appropriate recent developments such as use of cement as stabilizer and timber moulds as temporary forms for casting both CSRE walls and wall junctions have been applied in this construction. Three walling methods such as CSRE, cement concrete block work and cement stabilized earth bricks (CSEB) were used for this two storey house wherever required for this construction. 


\section{Objective}

Main objectives are to demonstrate the success in application of:

1) CSRE for constructing load bearing walls of two storey house amalgamating reinforced cement concrete (R.C.C.) components by following satisfactory structural design.

2) Wall finishes of CSRE for internal and external walls.

\section{Rammed earth technology}

Rammed earth comprises monolithic wall panels constructed with well graded sandy soil compacted in 100 to $150 \mathrm{~mm}$ thick layers between temporary movable formwork (Maniatidis \& Walker, 2003, Reddy \& Kumar, 2009). This earth technology has been successfully applied in Australia, New Zealand, Europe, Asia and many other countries (Walker, 2005). Rammed earth has also seen a revival as a modern construction technique, due to its low carbon content and inherent recycleability (Jaquin \& Augarde, 2006) Rammed earth could be considered as an alternative building material to be adopted in Sri Lanka (Kamaladasa \& Jayasinghe, 2005). Lot of research has been focused on rammed earth technology specially for putting up load bearing walls of buildings. Earth is the main natural material for making rammed earth walls which is available in any part of the island. Soil stabilization comprises a variety, and often combination, of modification processes to improve soil properties, including strength and resistance to water (Maniatidis \& Walker, 2003). Throughout its history as a building material, earth has been stabilized with different additives ((Isik \& Tulbentci, 2008). The use of stabilizers such as cement has derived out of a need to improve wet strength and erosion resistance in very exposed walls (Houben \& Guillaud, 1994). Stabilized rammed earth can be used as a direct replacement of other walling materials such as concrete block and fired bricks (Walker, 2005). Rammed Earth (RE) is enjoying a renewed interest in North America. Contemporary stabilized rammed earth (SRE) builds upon traditional RE and incorporates rigid insulation and reinforcing steel, enhancing the structural and energy performance of the walls while satisfying current building codes (Windstorm, 2011). Rammed earth, as any other form of earth construction, has relatively good strength in compression but generally poor strength in shear and tension, especially when moist (Maniatidis \& Walker, 2003). As the result of development of rammed earth technology, cement has been presently added for the purpose of stabilizing to gain high strength and durability. Cement stabilized rammed earth (CSRE) is the prolonged environmental friendly and thermal comfort technology for building up walls of single and two storey houses. The construction process of contemporary stabilized rammed earth utilizes modern equipment and Portland cement as a stabilizer, which can create walls of very high strength and durability (Windstorm, 2011). Cement stabilized rammed earth has been introduced to Sri Lankan housing sector in 2004 by performing laboratory testing for stabilized rammed earth, introducing CSRE wall junctions using timber moulds and implementing few housing projects successfully thereafter (Kamaladasa \& Jayasinghe, 2005 Kandamby, 2015, Kandamby, 2016).

\section{Structural design for CSRE walls}

Load bearing earth buildings have developed over millennia completely in the absence of structural design standards or codes and rules of thumb for geometric wall proportions developed through the experience of trial and error have proven sufficient to enable earth building to achieve at least ten stories high (Vasilios \& Walker, 2003). There were more than 600 historic earth buildings in New Zealand started from 1980s (Lydia Kiroff and Harry Roedel, 2010). New Zealand established relevant building codes from 1998 which gives good supports for the use rammed earth buildings in other countries. As part of the review standards and reference documents for earthen construction and some more specifically for rammed earth, from six countries are examined in some detail. Five of these national reference documents, two from Australia, New Zealand, USA (New Mexico), and Zimbabwe are written in English (Maniatidis \& Walker, 2003). The main aim of structural design is to ensure that a structure should fulfil its intended function throughout its lifetime without excessive deflection, cracking or collapse. The engineer is expected to meet this aim with due regard to economy and durability.

\section{Application of NZS codes}

Structural design for two critical locations of this house are presented in this paper by using NZS 4297 (1998) published by New Zealand for engineering design for earth buildings.

Soil cement mixture used for this house construction was 1:8 (cement: soil) ratio in volume. Compaction factor was derived while performing wall constructions in randomly selected wall panels. Average density of compacted soil mixture of 1:8 and average compaction ratio were found as 1983.94 $\mathrm{kg} / \mathrm{m}^{3}$ and 1.84 respectively (Kandamby, 2016).

Weight of soil mixture in $1 \mathrm{~m}^{3}$ compacted $\left(1.84 \mathrm{~m}^{3}\right.$ of loose volume) $=1983.94 \mathrm{~kg}$

Considering cement density in loose form is 1440 $\mathrm{kg} / \mathrm{m}^{3}$, weight of cement in $1 \mathrm{~m}^{3}$ of compacted soil mixture $=1 / 9 \times 1.84 \times 1440 \mathrm{~kg}=294.40 \mathrm{~kg}$

Percentage of cement in 1:8 soil mixtures by weight $=294.4 \div 1983.94=14.84 \%$ 
NZS codes for earth buildings can be applied (clause 1.2 of NZS 4298-1998). Strength obtained from experimental programme for local soil has been applied wherever it is necessary.

\section{Structural design of CSRE walls}

Layout of walls (A, B and C) and detailed load analysis are given in Appendix.

\section{A. Wall eccentricity}

Wall A

Total designed load on UF level $=47.56 \mathrm{kN} / \mathrm{m}$

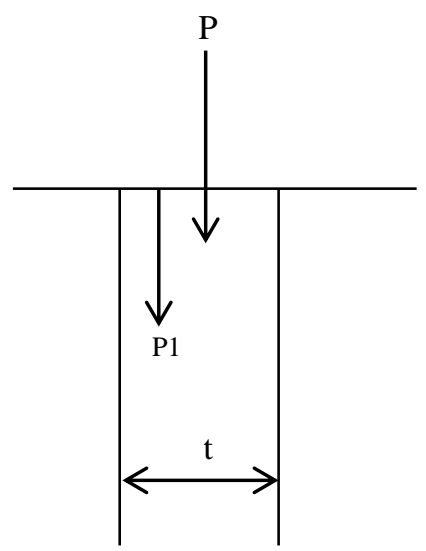

Fig. 1 Cross section of wall A near stair way

Consider critical section (stair way area) of wall A on ground level,

Equivalent effective eccentricity of wall A e,

$$
\begin{aligned}
& e=(P 1 \times t / 3) \div\left(P_{1}+P\right) \\
& =(7.58 \times t \div 3) \div(7.58+47.56)=0.046 t\langle 1 / 6 t
\end{aligned}
$$

Hence satisfactory



(a) Location 1

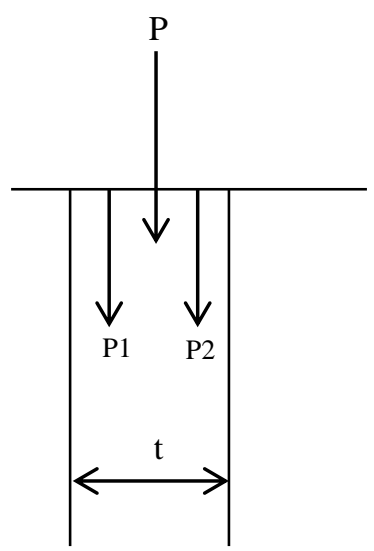

(b) Location 2
Fig. 2 Cross sections of wall B at two locations

Location 1, equivalent effective eccentricity e, (As Equation 1$)=$
$=(10.41 \times t / 6) /(19.97+10.41)=(10.41 \times t / 6) / 30.38$

$=0.057 t\langle 1 / 6 t$

Hence satisfactory

Location 2, equivalent effective eccentricity e,

$=\left(P_{1} \times t / 3-P_{2} \times t / 3\right) \div\left(P+P_{1}+P_{2}\right)$

$=(28.00 \times t / 3-7.88 t / 3) /(23.42+28.00+7.88)$

$=(20.12 \times t / 3) / 59.30=0.113 t\langle 1 / 6 t$

Hence satisfactory

\section{B. Allowable wall height and length}

Allowable height and length

$=18.0 \times t=18 \times 250=4.5 \mathrm{~m}$

Maximum wall length $=3.96 \mathrm{~m}$ and wall height $=2.73$ $\mathrm{m}, \mathrm{a}_{\mathrm{v}}=1.00$ (for member laterally supported and rotationally free at both top and bottom), effective height $=1.0 \times 2.73=2.73 \mathrm{~m}$, hence satisfactory.

\section{Concentrated load on CSRE wall}

Maximum axial load was considered. Concentrated load from beam on wall $\mathrm{C}$ Clause 6.4.3.4.2



Fig. 3 Wall B and C

According to clause 6.4.3.4.4,

$\mathrm{K}_{\mathrm{b}}=1.00$

$\mathrm{h}=2.73 \mathrm{~m}, \mathrm{~h} / 2=1.37 \mathrm{~m}$

Total designed load on beam $\mathrm{L}=51.42 \mathrm{kN} / \mathrm{m}$ Concentrated load $\mathrm{W}$ at upper floor level on wall B $51.42 \times(1.10+3.55) / 2=119.55 k N$

Designed load on effective area of load $w=119.55 / l_{e} \times t=119.55 / 1.37 \times 0.20=436.31 \mathrm{KN} / \mathrm{m}^{2}$ As per clause 6.4.3.4.3, maximum designed axial load on DPC level

$=436.31 \times 0.20+19.97+11.20+1.01=119.44 \mathrm{kN} / \mathrm{m}$

Considering critical location 2 of wall $\mathrm{B}$ in Figure above,

Equivalent effective eccentricity $e / t=0.113$

As per clause 6.4.3.3, Evaluation of slenderness ration $S r=a v h / t$

Wall thickness including plastering $=250 \mathrm{~mm}$,

Then $S_{r}=2.73 m / 0.25 m=10.90$

From linear interpolation from Table $6.1, \mathrm{k}=0.625$. 
As per clause 5.3.1.3, capacity reduction factor $\phi=0.60$ (axial compression and bending)

Design for compressive forces and vertical bending as per clause 6.4.3.2, $N^{*} \leq k \phi N_{o}$

Where, $k$ is taken from Table 6.1 and

$$
\begin{aligned}
& N_{o}=f_{e} \times A b \\
& N^{*}=119.44 k N / m \\
& 119.44 \leq k \phi f e \times A b \\
& f_{e} \geq 119.44 /(0.625 \times 0.60 \times 0.25) \\
& f_{e}>1.274 N / m m 2
\end{aligned}
$$

From the laboratory experiment for CSRE wall panels (Jayasinghe \& Kamaladasa, 2005) for different soil types have been determined as follows.

Table 1 Compressive strength of CSRE wall panels in cement and soil mixture 1:8

\begin{tabular}{|c|c|}
\hline Type of soil & $\begin{array}{c}\text { Compressive strength } \\
\mathrm{N} / \mathrm{mm}^{2}\end{array}$ \\
\hline Sandy & $3.06-3.99$ \\
Gravel & $1.84-2.09$ \\
Clay & $1.98-2.03$ \\
\hline
\end{tabular}

Value $\mathrm{f}_{\mathrm{e}}$ for soil type used for this house is in the range of 3.06 and $3.99 \mathrm{~N} / \mathrm{mm}^{2}$ which was checked with the field cube test results (Kandamby, 2016). Therefore CSRE wall under compressive forces and vertical bending is satisfactory for the above types of soils.

\section{Structural design against lateral forces}

In most areas wind loads should normally not be a problem for rammed earth walls satisfying the minimum requirements outlined (Vasilios \& Walker, 2003). Geometrical details of this two storey house have been checked as shown below and found that they are within the limitations specified in NZS codes NZS 4297:1998; NZS 4298:1998 and NZS 4299:1998 for earth buildings.

i. Maximum height of external wall from upper floor level to wall plate level $=2.75 \mathrm{~m}$

ii. Provided eave length $=1.0 \mathrm{~m}$

iii. Maximum height from finished ground level to ridge line $=6.0 \mathrm{~m}<8.0 \mathrm{~m}$

iv. Pitch of roof $=23^{\circ}<45^{\circ}$

v. Maximum height of the walls $=2.74 \mathrm{~m}<6.5 \mathrm{~m}$

vi. Floor area of this house, ground floor $=82 \mathrm{~m}^{2}$ and upper floor area $=40.5 \mathrm{~m}^{2}<300 \mathrm{~m}^{2}$ (Two storey building, floor area).

vii. Design wind speed for this house $=24.12 \mathrm{~m} / \mathrm{s}$ (analysis is given in Appendix) $<50 \mathrm{~m} / \mathrm{s}$

Hence effect from wind load is not necessary to be considered for these ground floor walls.

\section{Foundation of CSRE walls}

By referring article for economical design of foundation for load bearing walls published by Jayasinghe, 1999 T-type foundation with R.C.C. plinth beam and random rubble masonry (R.R.M.) footing and plinth wall were applied.



Fig. 4 Foundation of CSRE walls

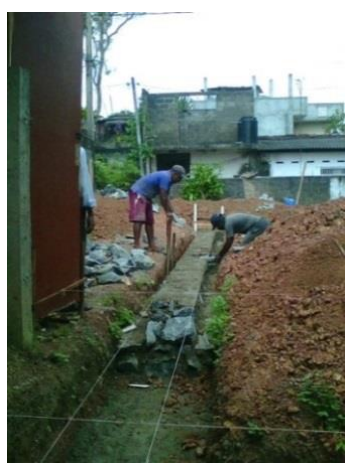

Fig. 5 Construction of foundation

Plinth beam with $200 \mathrm{~mm} \times 200 \mathrm{~mm}$ equal to thickness of the CSRE walls and four tor steel $10 \mathrm{~mm}$ diameter bars and mild steel $6 \mathrm{~mm}$ diameter stirrups at $200 \mathrm{~mm}$ centres were used so that plinth beams provide against tension and flexural resistance. Width of the foundation $750 \mathrm{~mm}$ is sufficient to bear the vertical load at the bottom of the foundation as sub soil of the land is very hard gravel. With the completion of top level of R.R.M plinth wall, brick facing was provided on both sides in order to cast R.C.C. plinth beam without timber shutters.

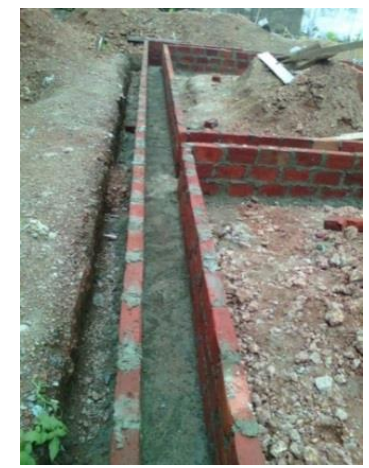

Fig. 6 Arrangement for plinth beam construction 
Grade 20 plinth beams were casted on rubble foundation with the support of brick facing laid on both sides without side planks of beam formwork. Timber mould is necessarily to be fixed on concrete plinth beam to put up CSRE walls. It was decided to provide $75 \mathrm{~mm}$ high grade 20 concrete kicker on top of foundation to place timber mould as it is usually made for casting columns with concrete. Setting out of CSRE walls were commenced by fixing timber moulds to these kickers at floor level.



Fig. 7 Construction of kicker for commencement of CSRE walls

\section{Construction of CSRE walls}

\section{A. Earth mixture}

Earth was bought from nearby borrow area ensuring proper gradation by performing jar tests while carrying out the construction of walls. A suitable soil can be considered to be one that has no organic material, has clay content between $10 \%$ and $20 \%$ and has a fair range of well distributed particle sizes up to a maximum of $20 \mathrm{~mm}$ in diameter (Montgomery, 1998). The minimum percentage of combined clay and silt should be between 20\%-25\% while the maximum between $30 \%-35 \%$. Similarly, the minimum percentage of sand should be between $50 \%-55 \%$ while the maximum is between 70\%-75\% (Maniatidis \& Walker, 2003). Maximum clay content for rammed earth is between 10 and 15\% (Delgado \& Guerrero, 2005). Presence of clay generally impedes effectiveness of cement stabilization and, therefore should be generally minimized (Vasilios \& Walker, 2003). Cement is typically used in proportions between $6 \%$ and $10 \%$. As a stabilizing material cement is well researched, well understood and its properties clearly defined (Montgomery, 1998). It has been recommended that earth having composition of $5-20 \%$ gravel, $45-60 \%$ sand, $20-35 \%$ silt and clay has good performance where earth can be visually checked by performing jar test (Jayasinghe \& Kamaladasa, 2006). The jar test is a field test used to establish approximate (volume) proportions of the main soil constituents (Maniatidis \& Walker, 2003). Particle size distribution testing by sieving and sedimentation testing has become acceptable practice for appraisal of soil for rammed earth (Maniatidis \& Walker, 2003). In order to determine tentative percentages of sand, silt and clay of soil particles, the soil was subjected to the sedimentation test in which each sample was placed in a glass jar (Arumala \& Gondal, 2007). In order to increase the compressive strength of rammed earth, the used soil should not be too clayey. An ideal soil contains $15-16 \%$ clay (Ciurileanu \& Horvath, 2012). In order to increase the compressive strength of rammed earth, the used soil should not be too clayey. An ideal soil contains $15-16 \%$ clay (Ciurileanu \& Horvath, 2012). Soil was then sieved using $5 \mathrm{~mm}$ mesh and stored for purpose of making walls free from large cavities. Any material coarser than $5-10 \mathrm{~mm}$ should be sieved out. Average composition of earth was gravel $24.6 \%$, sand $-57.4 \%$, silt and clay $-18.0 \%$. Stored soil was protected by covering with polythene sheets during rains for washing off the particles.

Experimental programme has been conducted for testing CSRE wall panels using different earth and cement proportions by performing manual tamping in order to select appropriate mixture when casting CSRE walls. It was decided to use 1:8 (cement and earth) mixture for this house construction as the compressive strength is usually varies from 1.84 to $3.99 \mathrm{~N} / \mathrm{mm}^{2}$ for clay to gravel soil (Jayasinghe \& Kamaladasa, 2006). High levels of cement stabilization improve the surface coating and reduce erosion (Walker, 2000). Earth and cement were measured by volume using a bucket and mixed with water by sprinkling water to the required quantity. The moisture of the soil-cement mixture needs to be carefully controlled. There needs to be sufficient moisture for the cement to fully hydrate but no excess of water which would reduce the final density, increase porosity and reduce final strength (Montgomery, 1998). Mixed soil ball was made by hand by pressing thoroughly and it was fallen from $1.0 \mathrm{~m}$ high and observed the way of bursting the ball. The ball bursts into 4 or 5 pieces is the correct water content stage in the mixture. A good first approximation of the optimum moisture content can be achieved using the drop test' (Maniatidis \& Walker, 2003).

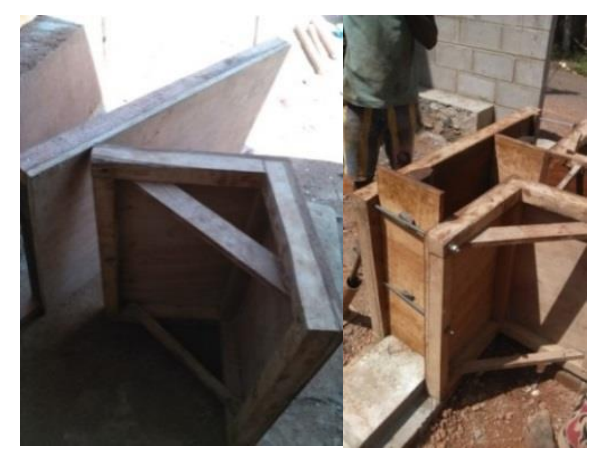

Fig. 8 Timber mould for casting CSRE walls

Different methods of wall construction have been practiced in order to find the economical ways of providing movable formwork for casting walls (Jayasinghe \& Kandamby, 2012, Kandamby, 2014). 
Timber moulds were made to suit to the $200 \mathrm{~mm}$ thick of CSRE walls with timber battens fastening with nut and bolts which were purposely made with $10 \mathrm{~mm}$ diameter mild steel bars for tying timber members steadily, easy fixing with hand tools and dismantling once casting walls were over. Colourless Mould oil was applied on the surfaces of the timber mould for the purpose of obtaining better finishing and easy dismantling from the face of the walls.

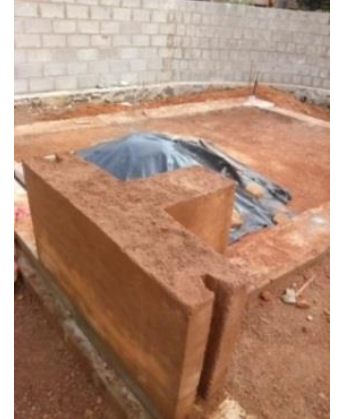

(a) Vertical joints



(b) Horizontal joints
Fig. 9 CSRE wall construction

\section{B. Control joints for CSRE walls}

Timber moulds have been fabricated providing end mechanical keys so that each CSRE walls have been jointed each other (Fig.9 a) allowing very good bond with the adjacent wall panel. When placing the mould for the adjacent panel, cement powder was placed on the surface of these groves providing tong and grove jointing method when casting the whole CSRE walls. Wall junctions were first casted (Fig 9 a) and walls were then built up by fixing moulds to the casted wall junctions. This method was supported to maintain line and level of the wall constructions. When making wall panels joints were staggered for allowing load distribution without cracking. Since CSRE walls have been placed in $600 \mathrm{~mm}$ height at a time (mould height) horizontal joints appeared in the way of it was casted. When placing the next $600 \mathrm{~mm}$ wall panel on top of the casted wall panel, the surfaces were wetted well and cement powder was placed to ensure proper bonding (horizontal) between these two wall panels (Fig. 9 b).

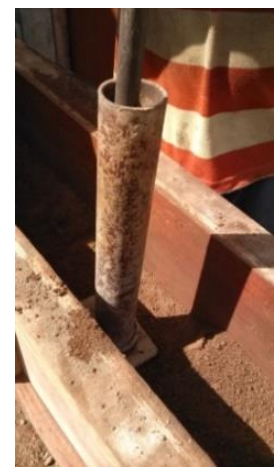

Fig. 10 Manual compaction with steel tamper
To make a rammed earth wall, soil is taken from the ground, poured into formwork and compacted in layers, usually around $100 \mathrm{~mm}$ deep (Jaquin \& Augarde, 2006). The basic principle is compaction of a soil mixture into rigid forms to create monolithic walls (Simenson, 2011). In this CSRE wall construction, about $100 \mathrm{~mm}$ thick earth layers were placed at once in the mould and compaction was carried out manually using steel tamper. All CSRE walls were completed up to $2.95 \mathrm{~m}$ height on ground floor level of the house by moving the timber moulds. Timber moulds were repaired when necessary or sometimes new moulds are to be provided while wall construction was going on to maintain good quality of the construction.

The curing of the cement within the soil needs to take place in the same way that it would in a wellmixed batch of concrete. Full strength will not be reached for many weeks and to help the cement hydrate fully the finished mixture should be kept in a $100 \%$ humidity environment for the curing period (Montgomery, 1998). Wet gunny bags were used for curing CSRE walls from the following day of casting.

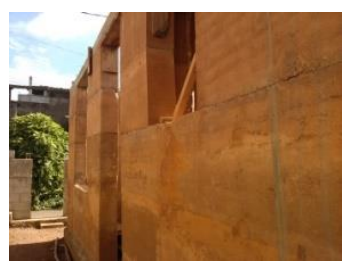

Fig. 11 Wall openings

\section{Wall openings}

Window and door frames which were made with timber by keeping $150 \mathrm{~mm}$ hones in both sides were securely placed on CSRE walls. Required spaces for these openings were kept while building walls using timber shutters. $50 \mathrm{~mm} \times 50 \mathrm{~mm}$ and $50 \mathrm{~mm} \times 25 \mathrm{~mm}$ timber members were inserted to receive neat and strong door and window jambs. Mild steel hold fasts with cement concrete were placed at appropriate locations and required spaces were kept while casting CSRE walls. Heads of doors and window frames were placed underside of the continuous lintel. Jambs of the doors and windows were finished together with the wall finishing.

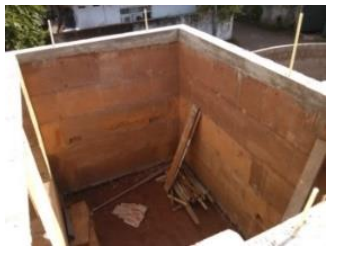

Fig. 12 R.C.C. continuous lintel

RC.C. continuous lintel having $200 \mathrm{~mm} \mathrm{x} 150 \mathrm{~mm}$ section was placed on top of the CSRE wall at same level (2.95 $\mathrm{m}$ from the D.P.C. level) where two numbers $10 \mathrm{~mm}$ diameter tor steel with $6 \mathrm{~mm}$ diameter mild steel links were used with grade 20 concrete. Only for high span locations of openings, $200 \mathrm{~mm}$ x $200 \mathrm{~mm}$ 
R.C.C. beams with four numbers $10 \mathrm{~mm}$ diameter tor steel with $6 \mathrm{~mm}$ diameter mild steel links were used with grade 20 concrete by maintaining $2.95 \mathrm{~m}$ level for placing composite upper floor slab. R.C.C. continuous lintel was provided on the top of the walls at $2.95 \mathrm{~m}$ high from ground floor level to receive the composite slab and stair way to this house. Composite slab system has been promoted in Sri Lanka as cost effective slab system and there is a possibility to purchase required components by submitting the house plans to these companies. There was no difficulty to place and construct composite slab system with these CSRE walls.

\section{Electrical wiring}

Plastic electrical conduits were laid according to the wiring diagram while casting CSRE walls. Arrangement was made to use small steel rod to compact the CSRE wall at these conduit locations to ensure proper compaction. Several conduits were placed closely at the location of main switch board.

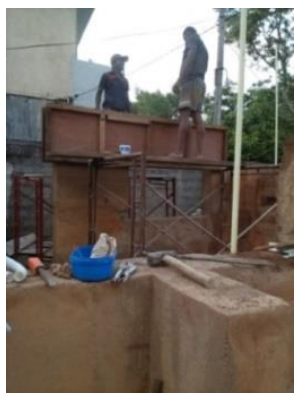

Fig. 13 Placing of electrical conduits

\section{E. Reinforced cement concrete beam and stairway}

R.C.C. beam having $200 \mathrm{~mm}$ x $300 \mathrm{~mm}$ section was designed to take upper floor wall load together with roof load. One end of this beam was placed on CSRE wall $\mathrm{C}$ on ground floor level where sufficient length of beam can be accommodated along this CSRE wall. The other end of the beam was simply supported with R.C.C. columns which was designed and constructed for the purpose of placing this beam. Design calculation was made by considering concentrated load coming on to the wall from this beam (see design calculation above). There were no unsatisfactory situations found while carrying out the structural design as per design code of NZS 4297: 1998.

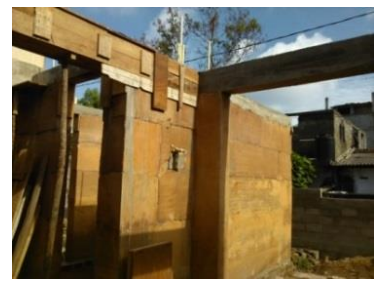

According to house plan stairway rests on CSRE wall A and the total load at floor level of this wall is less than the maximum load on wall $B$. Therefore construction of wall A was satisfied with the design requirements. Construction of CSRE wall together with R.C.C. beam and stairway was completed successfully as shown in Fig. 15 with wall finishes described below.


Fig. 15 Completed CSRE walls near beam and stairway

\section{Wall finishes}

The surface finish of rammed earth is a function of many variables and it is difficult to describe the ideal finish in terme of dimensional accuracy (Vasilios \& Walker, 2003). Many modern rammed earth buildings are coated with plaster and newer products like acrylic sprays are utilized as wall coatings that provide weatherproofing. Coatings, like acrylic, act as waterproofing, which helps prevent the wall from eroding due to moisture. Plaster and stucco coatings provide a durable exterior surface that takes the wear and tear from mother nature. It is routine maintenance to restore coatings at regular intervals (Simenson, 2011). According to the experiment performed for surface costing of cement stabilized erath walls by Arandara \& Jayasinghe in 2008, it is found that conventional plaster completed with emulsion and weathershield paints, Acrylic filler or ready mixed plaster could be recommended for cement stabilized walls as better surface coating and finishes in terms of minimizing the water absorption.

It was decide to finish the surfaces of internal and external walls of CSRE by platering with 1:1:6 (cement:sand:earth) covering the earth layer joints and some locations correct the verticality of walls. Same earth was used for this plaster application by seving from $2 \mathrm{~mm}$ mesh. Internal faces of walls were finished smoothly with skim coat powder and external walls were kept with semi rough finish.

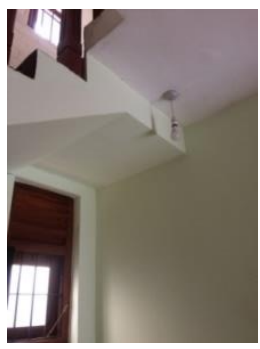

(a)Internal walls

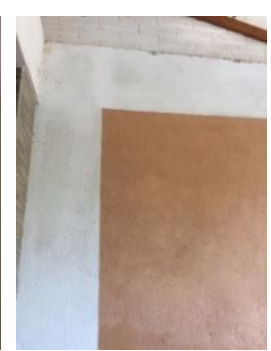

(b) External walls
Fig. 14 R.C.C. beam construction with CSRE wall 
All internal walls were treated with one coat of primer and two coats of emulsion (Fig. 16 a). External walls were completed with soil based rough render with one coat of primer and two coats of weather shield paints and one front wall of this house was kept by applying two coats of colourless Flex seal (Fig. 16 b).

\section{Quality control of CSRE wall construction}

It is very important to maintain the quality of construction while building walls as similar to other constructions. It was decided to maintain the quality of construction under the areas of selecting correct material (earth), providing supervision for mixing material, erecting moulds, placing and compacting to achieve acceptable compaction when tamping wall panels. Since earth was taken from one borrow area there was no such difference of the quality of earth. But, jar tests were carried out for each load to check the gradation of earth before it was used. Construction process of walls was carried out with the supervision and data was recorded for determination of work norm for construction of CSRE walls. This was one of the studies carried out using the same construction site and data published by Kandamby in 2016 has been presented below.

Average composition of earth was gravel - $24.6 \%$, sand $-57.4 \%$, silt and clay $-18.0 \%$

Achieved compaction factors for randomly selected wall panels were within the limits of 1.61 to 2.09.

It is noted that walls have to be casted by keeping high compaction value above 1.65 . Ultimate crushing strength from the test cubes casted at site were in the range of $4.58 \mathrm{~N} / \mathrm{mm}^{2}$ to $8.15 \mathrm{~N} / \mathrm{mm}^{2}$.

It can be stated that control quality of CSRE walls is possible at site in order to maintain its standards as expected.

Once construction of this house was totally completed including upper floor work in mid-2015, it was occupied. It is found that total wall construction was successful and there is no such deformation or cracks appeared at the critical loading case identified at beam supporting area and stair way supporting area of CSRE as revealed from the structural design.

\section{Conclusions}

1) Rammed earth is one of the earth building technologies prevailing from ancient times and it is being widely used for constructing load bearing walls of houses in most part of the world today by developing the way of designing and constructing.

2) Engineering design code for earth buildings NZS 4297:1998 can be used for designing these walls as per the requirements of the house plan by applying relevant strength parameters derived for local soils.

3) It is revealed that CSRE walls can be finished with cement concrete components and obtained the final finish with soil base plaster.
4) Emulsion and weather shield paints for internal and external surfaces of walls can be recommended for illuminating inside the house and providing attractive appearance.

\section{Reference}

Delgado, M.C.J. \& Guerrero, I.C. (2005), The selection of soils for unstabilized earth building: A normative review, Construction and building Materials 21, 237-251.

Arumala, J.O. \& Gondal, T. (2007), Compressed Earth Building Blocks for Affordable Housing, The construction and building research conference of the Royal Institution of Chartered Surveyors.

Bogahawatte, V.T.L., (1993), Science Educational Series: Building Materials in Sri Lanka, Natural Resources Energy and Science Authority, Sri Lanka, No.32.

Isik, B. \& Tulbentci, T. (2008), Sustainable hosing in island condition using Alker-gypsum-stabilized earth: A case study from northern Cyprus, Building and Environment 43 1426-1432.

Ciurileanu, G.T. \& Horvath, I.B. (2012), The use of cement stabilized rammed earth for building a vernacular modern house, Doctoral Studies in Engineering Sciences for Developing the Knowledge Based Society, project cofunded from European Social Fund through Sectorial Operational Program Human Resources 2007-2013.

Engineering design of earth buildings NZS 4297: 1998.

Earth building not requiring specific design NZS 4299: 1998.

Earth building materials and workmanship NZS 4298: 1998

Vasilios, M. and Walker P., 2003, A Review of Rammed Earth Construction, Natural Building Technology Group Department of Architecture and Civil Engineering, University of Bath, United Kingdom.

Reddy, B. V. V. \& Kumar, P. P., 2009, Compressive strength and elastic properties of stabilized rammed earth and masonry, Department of Civil engineering, Indian Institute of Science, Bangalore.

Walker, P. 2005, Rammed earth: design and construction guidelines, BRE Book shop, Great Britain.

Kiroff, L. \& Roedel, H., 2010, Sustainable construction technologies, earth buildings in New Zealand, Second international conference on sustainable construction materials and technologies.

Jaquin, P.A. \& Augarde, C.E. ((2006), Analysis of Historic Rammed Earth construction, Structural Analysis of Historical Constructions, New Delhi.

Jayasinghe, C. \& Kamaladasa, N., 2005, Structural properties of cement stabilized rammed earth, ENGINEER Journal of the Institution of Engineers, Sri Lanka, vol. xxxviii. no.03, Sri Lanka, pp.23-30.

Kamaladasa N. \& Jayasinghe, C. 2005, 'Development of efficient construction technique for rammed earth', Annual Transaction of Institution of Engineers, Sri Lanka, Engineer 2005, Sri Lanka.

Houben, H. and Guillaud, H. (1994). Earth construction - A comprehensive guide. Intermediate Technology publications 1994, London.

Windstorm, B. (2011), A report of contemporary rammed earth construction and research in north America, International Workshop on Rammed Earth Materials and Sustainable Structures, China.

Kandamby G.W.T.C., 2015, two storey cement stabilized rammed earth house, Case study, Transaction of Institution of Engineers, Sri Lank, pp 15-22.

Kandamby G.W.T.C., 2016, Work norm for cement stabilized rammed earth wall, Transaction of Institution of Engineers, Sri Lank, pp 87-93. 
MTR Jayasinghe, 1999, Foundation improvement techniques for brick wall structures, Journal of Institute of Engineers, Sri Lanka.

Montgomery, D.E. (1998), How does cement stabilisation work? , Stabilised Soil Research Progress Report SSRPR2.

Ministry of Local Government, Housing and Construction 1980, Design of buildings for high winds, Sri Lanka, Sri Lanka, pp. 4-14 \& 59.

Kandamby G.W.T.C. 2014, 'Design and construction cement stabilized rammed earth walls for single storey housing Case study', Annual Transaction of Institution of Engineers, Sri Lanka, pp 19-26.

Kanda,by G.W.T.C, 2015, 'Two storey cement stabilized rammed earth house - Case study', Annual Transaction of Institution of Engineers, Sri Lanka, - 2016, Sri Lanka.

Arandara, K.P. \& Jayasinghe, C. 2008, Surface coating for stabilized earth walls, Annual Transaction of Institution of Engineers, Sri Lanka, pp 20-30.

\section{Appendix}

\section{Loads analysis of CSRE of two storey house}

\section{A. Roof}

Timber roof frame and asbestos roof covering have been used.

Roof dead load on plan $=1.19 \mathrm{kN} / \mathrm{m}^{2}$

Roof imposed load $=0.75 \mathrm{kN} / \mathrm{m}^{2}$

Designed roof load,

$\left(1.4 G k+1.6 Q_{k}\right)$

\section{B. Wall}

A broad range of dry density values are quoted for rammed earth, varying from $1700 \mathrm{~kg} / \mathrm{m} 3$ to 2200 kg/m3 (Adam, 1995; Standards Australia, 2002; Houben \& Guillaud. 1994). Consider most critical wall (wall A) for this analysis. Thickness of CSRE ground floor walls are $250 \mathrm{~mm}$ and upper floor CSEB walls are $150 \mathrm{~mm}$.

Maximum vertical load on upper floor level of wall $\mathrm{A}=$ $33.95 \mathrm{kN} / \mathrm{m}$

\section{Floor slab}

Reinforced cement concrete (R.C.C.) composite slab system has been used for house as it is the most economical way of constructing floor slab.

Self-load of slab on wall $A=12.26 \mathrm{kN} / \mathrm{m}^{2}$

Imposed load of slab on wall $A=6.77 \mathrm{kN} / \mathrm{m}^{2}$

\section{Stair way}

R.C.C. in-situ stair way has been designed for this house. Designed dead load of stair way is $6.25 \mathrm{kN} / \mathrm{m}$ and imposed load is $2.0 \mathrm{kN} / \mathrm{m}$.

Wall A

Designed load on wall plate level wall A,

$=1.4 \times 5.60+8.15 \div(2 \times 0.56)+6.57 \div(2 \times 0.56)$

$=21.09 \mathrm{kN} / \mathrm{m}$

Designed load on lintel on door opening in UF,
$=1.4 \times 0.15 \times 0.76 \times 20+21.09=24.28 \mathrm{kN} / \mathrm{m}$

Concentrated load from lintel on UF,

$=24.28 \times 1.22 / 2=14.81 \mathrm{kN}$

Designed load on horizontal plane at half height of door in UF $=14.81 \div(0.50 \times 1.98)=14.96 \mathrm{kN} / \mathrm{m}$

Total designed load on UF level,

$=21.09+14.96+11.51=47.56 \mathrm{kN} / \mathrm{m}$

Wall B

Dead load on wall plate level,

$=6.62 \times 10 \div 1000+1.19(1.0+2.66 / 2)=2.84 \mathrm{kN} / \mathrm{m}$

Imposed load $=0.75(1.0+2.66 / 2)=1.75 \mathrm{kN} / \mathrm{m}$

\section{E. Concentrated load from beam on wall C}

Total designed load on beam $\mathrm{L}=23.42+28.00 \mathrm{kN} / \mathrm{m}=$ $51.42 \mathrm{kN} / \mathrm{m}$

Maximum designed axial load on DPC level per $\mathrm{m}$ length $=436.31 \times 0.20+19.97+11.20+1.01$

$=119.44 \mathrm{kN}$

\section{Lateral load calculation - Wind load}

\section{A. Wind speed factors}

Cl. 4.3 of CP 3: Chapter V: Part 2: 1972,

Design wind speed $V s=S_{1} \times S_{2} \times S_{3} \times V$

Where $V$ is the basic wind speed of zone 3 area which is taken as $33.50 \mathrm{~m} / \mathrm{s}$ (refer high wind manual of Sri Lanka)

Considering the topography, ground roughness of the land,

$S_{1}$ can be taken as 1.0 (Table 2 of the wind code) and $S_{2}$ $=0.720$ (Table 3 of the wind code) for all walls of this house.

Factor $S_{3}$ (Cl.5.6 of CP 3: Chapter V: Part 2: 1972) = 1.0

Therefore design wind speed,

$V_{s}=S_{1} \times S_{2} \times S_{3} \times V$

$=1.0 \times 0.720 \times 1.0 \times 33.5 \mathrm{~m} / \mathrm{s}$

$=24.12 \mathrm{~m} / \mathrm{s}$

Door height $=1.98 \mathrm{~m}$

Wall height $=2.74 \mathrm{~m}$

Arch height $=2.80 \mathrm{~m}$

Wall height $=2.8 \mathrm{~m}$

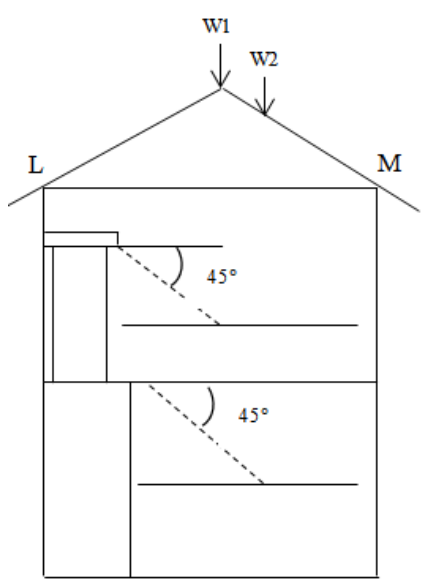

Fig. 17 Section of house 
Table 2 Summary of load calculation

\begin{tabular}{|c|c|c|c|c|}
\hline Components & Design Load & Wall A & Wall B & Wall C \\
\hline Roof & $\begin{array}{c}\text { Uniformly distributed load- } \mathrm{kN} / \mathrm{m} \\
\mathrm{W} 1-\mathrm{kN} \\
\mathrm{W} 2-\mathrm{kN}\end{array}$ & $\begin{array}{l}8.15 \\
6.57\end{array}$ & $\begin{array}{c}6.78 \\
- \\
-\end{array}$ & $\begin{array}{c}8.95 \\
- \\
-\end{array}$ \\
\hline Wall & $\begin{array}{c}\text { Above wall plate level }-\mathrm{kN} / \mathrm{m} \\
\text { Vertical load at wall plate level }-\mathrm{kN} / \mathrm{m}\end{array}$ & $\begin{array}{c}5.6 \\
21.09 \\
\end{array}$ & - & - \\
\hline Slab & $\begin{array}{c}\text { Uniformly distributed load- } \mathrm{kN} / \mathrm{m} \\
\text { Maximum }\left(1.4 \mathrm{G}_{\mathrm{k}}+1.6 \mathrm{Q}_{\mathrm{k}}\right) \mathrm{P}_{1} \\
\text { Minimum }\left(0.9 \mathrm{G}_{\mathrm{k}}+1.6 \mathrm{Q}_{\mathrm{k}}\right) \mathrm{P}_{1} \\
\text { Designed slab load on left side( T beam is spanning parallel } \\
\text { to wall } \mathrm{A})-\mathrm{p}_{2} \\
\text { Maximum }\left(1.4 \mathrm{G}_{\mathrm{k}}+1.6 \mathrm{Q}_{\mathrm{k}}\right) \mathrm{P}_{2} \\
\text { Minimum }\left(0.9 \mathrm{G}_{\mathrm{k}}+1.6 \mathrm{Q}_{\mathrm{k}}\right) \mathrm{P}_{2}\end{array}$ & $\begin{array}{c}7.58 \\
6.29 \\
0\end{array}$ & $\begin{array}{c}10.41 \\
7.88\end{array}$ & $\begin{array}{l}28.00 \\
21.87\end{array}$ \\
\hline Upper floor level & Total load on Upper floor & 11.51 & 12.18 & 12.45 \\
\hline Continuous lintel & Continuous lintel load or beam at UF level $-\mathrm{kN} / \mathrm{m}$ & 1.01 & 1.01 & 2.02 \\
\hline \multirow[t]{3}{*}{ Stairway } & Stair way load on slab level $-\mathrm{kN} / \mathrm{m}$ & 31.07 & - & - \\
\hline & Total designed load P on UF- kN/m & & 19.97 & 23.42 \\
\hline & $200 \mathrm{~mm}$ thick CSRE wall in ground floor $-\mathrm{kN} / \mathrm{m}$ & 11.2 & 11.2 & 11.2 \\
\hline
\end{tabular}



Fig. 18 Wall layout in ground floor 